\title{
The 'Alice in Wonderland' mechanics of the rejection of (climate) science: simulating coherence by conspiracism
}

\author{
Stephan Lewandowsky',2 . John $\operatorname{Cook}^{2,3}$. \\ Elisabeth Lloyd ${ }^{4}$
}

Received: 18 February 2016 / Accepted: 4 August 2016 / Published online: 19 September 2016 (C) The Author(s) 2016. This article is published with open access at Springerlink.com

\begin{abstract}
Science strives for coherence. For example, the findings from climate science form a highly coherent body of knowledge that is supported by many independent lines of evidence: greenhouse gas (GHG) emissions from human economic activities are causing the global climate to warm and unless GHG emissions are drastically reduced in the near future, the risks from climate change will continue to grow and major adverse consequences will become unavoidable. People who oppose this scientific body of knowledge because the implications of cutting GHG emissions - such as regulation or increased taxation-threaten their worldview or livelihood cannot provide an alternative view that is coherent by the standards of conventional scientific thinking. Instead, we suggest that people who reject the fact that the Earth's climate is changing due to greenhouse gas emissions (or any other body of well-established scientific knowledge) oppose whatever inconvenient finding they are confronting in piece-meal fashion, rather than systematically, and without considering the implications of this rejection to the rest of the relevant scientific theory and findings. Hence, claims that the globe "is cooling" can coexist with claims that the "observed warming is natural" and that "the human influence does not matter because warming is good for us." Coherence between these mutually contradictory opinions can only be achieved at a highly abstract level, namely that "something must be wrong" with the scientific evidence in order to justify a political position against climate change mitigation.
\end{abstract}

$凶$ Stephan Lewandowsky

Stephan.Lewandowsky@bristol.ac.uk

1 University of Bristol, Bristol, England

2 University of Western Australia, Perth, WA, Australia

3 University of Queensland, Brisbane, QLD, Australia

4 Department of History and Philosophy of Science and Medicine, Indiana University, Bloomington, IN 47401, USA 
This high-level coherence accompanied by contradictory subordinate propositions is a known attribute of conspiracist ideation, and conspiracism may be implicated when people reject well-established scientific propositions.

Keywords Climate science denial · Consistency · Coherence · Rationality • Conspiratorial thinking · Conspiracy · Global warming · Coherence in science

" $\mathrm{CO}_{2}$ keeps our planet warm ...."

— Ian Plimer, Australian climate "skeptic", Heaven \& Earth, p. 411

"Temperature and $\mathrm{CO}_{2}$ are not connected."

— Ian Plimer, Australian climate "skeptic", Heaven \& Earth, p. 278

"Why, sometimes I've believed as many as six impossible things before breakfast."

— The White Queen, in Through the Looking-Glass, and What Alice Found

There

\section{Introduction}

Over the last 150 years, climate scientists have built an increasingly clear picture of how the greenhouse gas (GHG) emissions that arise from human economic activity are changing the Earth's climate e.g., IPCC (2013). Current atmospheric $\mathrm{CO}_{2}$ levels are higher than at any time since at least 2.6 million years ago (Masson-Delmotte et al. 2013, Fig. 5.2), and the consensus position that global warming is happening, is human caused, and presents a global problem is shared by more than $95 \%$ of domain experts and more than $95 \%$ of relevant articles in the peer-reviewed literature (Anderegg et al. 2010; Cook et al. 2013, 2016; Doran and Zimmerman 2009; Oreskes 2004; Shwed and Bearman 2010).

Nonetheless, a small but vocal group of contrarian voices exists-mainly outside the scientific community - that deny that greenhouse gases cause climate change or that dismiss the risk of adverse consequences (e.g., Dunlap and McCright 2011; Lewandowsky et al. 2013a, c). This dissent almost never finds expression in the peerreviewed literature (Cook et al. 2013), and when it does, the research typically does not withstand scrutiny (Abraham et al. 2014; Benestad et al. 2015). Instead, the staging ground for climate science denial ${ }^{1}$ tends to involve internet blogs and other social media (e.g., Jang and Hart 2015; Lewandowsky et al. 2013c).

There is strong evidence that the rejection of climate science is primarily driven by ideological factors. Because cutting GHG emissions requires interventionssuch as regulation or increased taxation - that interfere with laissez-faire free-market

\footnotetext{
1 In current scholarly usage the term "denial" is often reserved to describe an active public denial of scientific facts by various means, such as the use of rhetoric to create the appearance of a scientific debate where there is none (Diethelm and McKee 2009; McKee and Diethelm 2010). We use denial as a noun that describes a political or discursive activity but we avoid labels such as "denier" or "denialist" that categorize people. There are people who deny scientific facts, but they are not "deniers" - they are people who choose to engage in a particular behavior.
} 
economics, people whose identity and worldview centers around free markets are particularly challenged by the findings from climate science (e.g., Dunlap and McCright 2008; Dunlap and Jacques 2013; Lewandowsky et al. 2013a, c; McCright et al. 2013, 2014).

When a person's worldview and identity, or their livelihood, are threatened by the regulatory implications of climate change, or other environmental risks, they frequently engage in "identity-protective cognition" (Kahan et al. 2007). Identityprotective cognition can manifest itself in a variety of ways. Perhaps the most frequent manifestation is that it moderates people's risk perceptions (Kahan et al. 2007). However, the overwhelming scientific consensus about the causes and risks of climate change — and the impetus for mitigative policies it entails_- poses a particular dilemma for people whose identity is threatened by any potential interference with the free market. A mere moderation of risk perception may be insufficient to enable identityprotective cognition in light of the particular challenges posed by the consensus. We suggest that the only cognitive and argumentative options open to identity-protective cognition are either to deny the consensus or to discredit it.

\subsection{The inconvenient consensus}

Some groups have endeavored to deny the consensus by creating a chimerical community of ostensibly dissenting scientists (Oreskes and Conway 2010). One clear example is the "Oregon Petition", an internet-based collection of more than 30,000 signatories who claim to be "scientists" but are opposing the consensus on climate change. In fact, only a small minority of signatories claim to have a PhD in climate science, and even among those the proportion of active researchers appears to be negligible (Anderson 2011).

Another option for contrarians is to accept the consensus (at least tacitly), but to glorify the few contrarian scientists as heros, often by appealing to Galileo (Mann 2015), who oppose the "corrupt" mainstream scientific "establishment." To illustrate, an Australian organization that is dedicated to the opposition to climate science and any mitigation policies calls itself the "Galileo Movement" (http://galileomovement. com.au/). A frequent component of this option is to seek an alternative explanation for the existence of the tacitly-accepted consensus. Instead of accepting the consensus as the result of researchers independently converging on the same evidence-based view, it can be explained via the ideation of a complex and secretive conspiracy among researchers (Diethelm and McKee 2009; McKee and Diethelm 2010). Around $20 \%$ of U.S. residents have been found to endorse the idea that climate change "is a hoax perpetrated by corrupt scientists who wish to spend more taxpayer money on climate research" (Lewandowsky et al. 2013a). Likewise, many climate contrarian books are suffused with conspiratorial themes (Lewandowsky et al. 2015a), and when contrarians were asked to indicate their affective responses to climate change, the most common response was conspiratorial in nature, with people frequently citing terms such as "hoax" (Smith and Leiserowitz 2012). When people's responses to consensus information (i.e., a statement that $97 \%$ of climate scientists agree on the fundamentals of greenhouse gas driven climate change) are modeled using Bayesian networks, it has been found that for the small segment of the U.S. 
public who are extremely strong supporters of free market economics, this information activated distrust in climate scientists and ironically, led to a reduction in acceptance of fundamental facts about the climate (Cook and Lewandowsky 2016). The decrease in trust in response to information about expert agreement is compatible with the assumption that people invoke the notion of a conspiracy to escape the implications of the consensus. Accordingly, there is ongoing fascination on contrarian blogs with the "climategate" event of 2009, which arose when climate scientists' private emails were stolen and released on the internet. Those emails were interpreted as constituting evidence of scientific impropriety, and although these allegations were eventually found to be groundless by 9 independent investigations around the world, on contrarian blogs the rhetorical activity devoted to "climategate" more than doubled between 2010 and 2013 (Lewandowsky 2014). One known element of conspiratorial thinking is its "self-sealing" quality (Bale 2007; Keeley 1999; Sunstein and Vermeule 2009), whereby evidence against a conspiratorial belief is reinterpreted as evidence for that belief. In the case of climategate, this self-sealing quality becomes apparent not just through the increasing blog fascination with "climategate" despite 9 exonerations - which represent strong evidence against any wrong-doing by scientists-but also by U.S. Representative Sensenbrenners public branding of exonerations as "whitewash" (http://republicans.globalwarming.sensenbrenner.house.gov/ press/PRArticle.aspx?NewsID=2799).

In summary, there is growing evidence for an involvement of conspiracist ideation in the rejection of climate science, both in public discourse and on internet blogs. This finding is unsurprising in light of long-standing knowledge that conspiracist ideation is also involved in the rejection of other well-established scientific propositions, such as the link between the HIV virus and AIDS (Bogart and Thorburn 2005; Kalichman 2009) and denial of the safety or benefits of vaccinations (Briones et al. 2012; Kata 2010; Zimmerman et al. 2005). However, research to date has mainly focused on the prevalence of such beliefs and their association with attitudes towards science (Lewandowsky et al. 2013a,c), or on examining the content of blog discourse and establishing its conspiracist attributes in blind tests (Lewandowsky et al. 2015a). In this article, we broaden the enquiry of conspiracist ideation to an analysis of the (pseudo-) scientific arguments that are advanced against the scientific consensus on climate change, and how they contrast with the positions of the scientific mainstream.

\subsection{Scientific coherence vs. conspiracist incoherence}

A broad stream of opinion among philosophers of science holds that coherence of explanations or theories is a necessary or at least "conducive" criterion for truth (e.g., Douglas 2013; Laudan 1984; Roche 2014; Thagard 2012). Coherence here refers to the criterion that propositions within the theory must not be contradicting each other-for example, the Earth cannot both be round and flat, and global warming cannot simultaneously be a serious human-caused risk and a natural fluctuation of no concern. Although the epistemological status of coherence is contested (e.g., Glass 2007; Olsson 2005; Schubert 2012), and although even coherent theories can turn out 
to be wrong (Oreskes 1999), arguably there is little room for incoherent theories in science. $^{2}$

For the case of climate change, Thagard and Findlay (2011) showed how the mainstream scientific position, namely that GHG emissions from human economic activities are causing the Earth to warm, is coherent and accounts for the available evidence. Their computer simulation of belief revision came to accept the scientific evidence because it maximized coherence among the various pieces of evidence and explanatory propositions.

Conversely, a known attribute of conspiracist thought is that it can appear incoherent by conventional evidentiary criteria. To illustrate, when people reject an official account of an event, they may simultaneously believe in mutually contradictory theories - e.g., that Princess Diana was murdered but also faked her own death (Wood et al. 2012). The incoherence does not matter to the person rejecting the official account because it is resolved at a higher level of abstraction; there is an unshakable belief that the official account of an event is wrong. Thus, “...the specifics of a conspiracy theory do not matter as much as the fact that it is a conspiracy theory at all" (Wood et al. 2012, p. 5). For the case of climate change, Thagard and Findlay (2011) showed that the contrarian position, exemplified by the opinion that global warming is a natural fluctuation, is incoherent in comparison to the mainstream scientific position. Thagard and Findly were nonetheless able to model why people might accept the incoherent contrarian position by adding emotional components (such as "avoid government intervention") to the simulation of belief acquisition. However, the possibility that climate-contrarian discourse is inherently incoherent has not been systematically examined. In the remainder of this article, we provide a preliminary analysis along those lines by analyzing 7 incoherent positions in detail, before summarizing others briefly.

\subsection{Alice-in-Wonderland states of denial}

Although (in-)coherence is a nuanced concept that is not readily measured (Glass 2007), for present purposes we define incoherence as the simultaneous acceptance or simultaneous proffering of two or more explanatory propositions that cannot be all true at the same time. For example, the proposition that Princess Diana was murdered cannot also be true if the proposition that she has faked her own death is true. Similarly, the quotations of Australian climate "skeptic" Ian Plimer at the outset of this article (Plimer 2009) are incoherent. It cannot simultaneously be true that " $\mathrm{CO}_{2}$ keeps our planet warm ..." and that "Temperature and $\mathrm{CO}_{2}$ are not connected." We next show that this incoherence suffuses the public posture of climate science denial, suggesting that it cannot lay a strong claim to scientific or intellectual credibility. We begin by considering the public discourse of denial in the aggregate, where incoherence is introduced by multiple actors, before returning to the level of incoherent statements by single individuals.

2 The case of the incompatibility of quantum mechanics and relativity is an exception, one that has provoked much concern among both philosophers and scientists, thus proving the general point that incoherence is undesirable. 


\subsubsection{Climate sensitivity is low but it is high}

One of the most important, but uncertain, variables that determines the extent of future warming is climate sensitivity, defined as the warming that is ultimately expected in response to a doubling of atmospheric $\mathrm{CO}_{2}$ concentrations from preindustrial times (e.g., Lewandowsky et al. 2014). If sensitivity is high, then continued emissions will increase global temperatures more than when it is low. Low estimates of sensitivity (e.g., $\approx 1.5^{\circ} \mathrm{C}$; Lewis and Curry 2014 ) are therefore favored by contrarians, with higher values within the range of consensual IPCC estimates-between 1.5 and $4.5^{\circ} \mathrm{C}$ (Freeman et al. 2015)—being ignored or labeled "alarmist."

Another popular contrarian argument is that the "climate has changed before", which frequently carries the tacit or explicit rhetorical implication that present-day climate change is similarly due only to the natural factors that drove past climate changes. This implication is a logical fallacy because the same effect can have multiple causes: Past climate changes were largely driven by slight variations in solar intensity arising from orbital variations or solar cycles, and those events are entirely independent of contemporary GHG-driven global warming. Moreover, the appeal to past periods of warming also entails a commitment to high climate sensitivity: if climate sensitivity were as low as contrarians like to claim $\left(\approx 1.5^{\circ} \mathrm{C}\right)$, then the minute past variation in intensity of insolation could not have caused the observed warming episodes (PALAEOSENS 2012).

Either the climate changed in the past because it is highly sensitive to external forces, in which case we are facing considerable future warming, or its sensitivity to the forces triggered by increasing $\mathrm{CO}_{2}$ concentrations is low, in which case the climate should not have changed much in the past. Except that it did.

\subsection{2 $\mathrm{CO}_{2}$ cannot be measured but lags behind temperature}

Past levels of atmospheric $\mathrm{CO}_{2}$ are known with considerable precision from analysis of Antarctic ice cores dating back 400,000 years. One contrarian argument holds that those measurements are unreliable and do not tell us about past $\mathrm{CO}_{2}$ levels (Jaworowski 1997).

A notable aspect of past climate changes is that atmospheric $\mathrm{CO}_{2}$ increased after an initial increase in temperatures primarily in Antarctica. This occurs because the initial solar-driven warming that is focused on extreme latitudes is sufficient to trigger the release of $\mathrm{CO}_{2}$ from the oceans into the atmosphere (because solubility of $\mathrm{CO}_{2}$ in water decreases with increasing temperature), which in turn amplifies warming and hence leads to more release of $\mathrm{CO}_{2}$ from the oceans, and so on. Overall, more than $90 \%$ of the warming observed during the glacial-interglacial followed the increase in $\mathrm{CO}_{2}$ whereas less than $10 \%$ preceded the release of $\mathrm{CO}_{2}$ and was due to the initial solar pulse (Shakun et al. 2012). ${ }^{3}$ By focusing on the lag between temperature increase and $\mathrm{CO}_{2}$ increase in Antarctica, and by ignoring the fact that warming occurs after the $\mathrm{CO}_{2}$ increase across most of the globe, contrarians have argued that $\mathrm{CO}_{2}$ was not the

\footnotetext{
3 The full picture is more nuanced and includes several other feedbacks and processes than can not be presented here.
} 
cause of warming in the past but a consequence. By extension, $\mathrm{CO}_{2}$ also cannot be the cause of warming in the present but must be a consequence of warming that is caused by some other means. (Additionally, this argument relies on a false dichotomy because, like chickens and eggs, increasing atmospheric $\mathrm{CO}_{2}$ can both be the consequence and the cause of warming.)

Either the ice core record is sufficiently accurate to sustain arguments about the role of $\mathrm{CO}_{2}$ in past climate changes, or it is unreliable and therefore does not permit any argument either way. There are several additional variants of this incoherence: For example, some contrarians have argued that contemporary $\mathrm{CO}_{2}$ levels cannot be measured with any degree of accuracy (Beck 2008), whereas others have claimed that $\mathrm{CO}_{2}$ increases because of emissions from underwater volcanoes (Plimer 2010).

\subsubsection{Global temperature cannot be measured accurately but global warming stopped in 1998}

A long-standing contrarian argument has been that the global temperature record is inaccurate and that therefore global warming cannot be measured accurately (Watts 2009). This argument has often appealed to the presence of "urban heat islands"; that is, the trapping of heat in large urban areas which has increased with greater traffic volumes and economic activity. Alternatively, the argument cites the fact that thermometers may be located near airports or air conditioner exhausts, thereby distorting and artificially amplifying the temperature trend. Another variant of the argument cites adjustments to the temperature record (which are necessary to compensate for variables such as the movement or replacement of thermometers over time) as introducing a warming bias. The scientific literature has shown that those arguments have no qualitative impact on the observed warming trend (e.g., Fall et al. 2011; Smith et al. 2005).

Another long-standing contrarian claim has been that global warming "stopped" in 1998 (e.g., Carter 2006). Although this claim is based on a questionable interpretation of statistical data (Lewandowsky et al. 2015b, c, d), it has been a focal point of media debate for the last decade or more and it has ultimately found entry into the scientific literature under the label of a "pause" or "hiatus" in warming (Boykoff 2014).

Either the temperature record is sufficiently accurate to examine its evolution, including the possibility that warming may have "paused", or the record is so unreliable that no determination about global temperatures can be made. ${ }^{4}$

\subsubsection{There is no scientific consensus but contrarians are dissenting heroes}

The pervasive scientific consensus on climate change (Anderegg et al. 2010; Cook et al. 2013; Doran and Zimmerman 2009; Oreskes 2004; Shwed and Bearman 2010; for a synthesis of studies quantifying the consensus on climate change, see Cook et al. 2016) is of considerable psychological and political importance. The public's

\footnotetext{
4 A possible escape from incoherence is to soften the claim about the data being unreliable to "the data exaggerate warming". Warming might indeed have stopped if the data over-estimate warming.
} 
perception of the consensus has been identified as a "gateway belief" van der Linden et al. (2015) that plays an important role in influencing people's acceptance of policy measures. When people are informed about the broad nature of the consensus, this often alters their attitudes towards climate change (Cook and Lewandowsky 2016; Lewandowsky et al. 2013b; van der Linden et al. 2015).

Contrarian efforts to undermine the perception of the consensus have therefore been considerable. For example, the top argument leveled against climate change by syndicated conservative columnists in the U.S. between 2007 and 2010 was the claim that there is no scientific consensus (Elsasser and Dunlap 2013). Other efforts involve the creation of large lists of "scientists" who ostensibly deviate from the consensus, such as the "Oregon Petition", which claims more than 31,000 signatories who express their dissent from the consensus view (Dunlap and McCright 2010; Anderson 2011). Only a small number of signatories, however, turn out to be actual scientists with expertise in climate change (Anderson 2011).

A parallel stream of contrarian discourse highlights the heroism of the lone contrarian scientist who dissents from the "establishment" and fearlessly opposes "political persecution and fraud" (e.g., Solomon 2008).

Either there is a pervasive scientific consensus in which case contrarians are indeed dissenters, or there is no consensus in which case contrarian opinions should have broad support within the scientific community and no fearless opposition to an establishment is necessary.

\subsubsection{The climate cannot be predicted but we are heading into an ice age}

The argument that future climate change cannot be predicted with any accuracy is commonly expressed in the form that weather forecasters cannot predict next week's weather, so how can they possibly predict climate over the next century (Hickman 2010). This argument is fallacious because it conflates weather (short-term, localised changes subject to internal variability) with climate (long-term, wide-scale regional or global changes driven largely by external forcing). Predictions of the former are highly sensitive to imprecision in the estimates of initial values (i.e., the current state of weather) and hence lose skill after several days, whereas projections of the latter are insensitive to initial values, and are instead aggregated across numerous possible initial states to extract the long-term anthropogenic climate signal from among the natural variability. An intuitive everyday example of this ability to project future climate is the seasonal cycle: we can state with considerable confidence that Minnesota will always be warmer in July than in January.

Setting aside the fallacious nature of the argument regarding weather forecasts, contrarians have also argued that the future climate is headed towards an ice age, most commonly attributed to decreased solar activity (Johnson 2013). This prediction has been falsified by climate modelling that found that decreased solar activity will have a miniscule effect compared to the warming effect from greenhouse gas emissions (Feulner and Rahmstorf 2010). Setting aside falsification of the prediction, the inherent contradiction in this pair of arguments is to argue that future climate cannot be predicted while also predicting a future ice age (Rose 2010). 
Either we cannot know what happens in the future, in which case predictions of an ice age are entirely fantastical, or we can in principle anticipate how the climate will evolve in the future, in which case climate projections cannot be dismissed by a blanket appeal to ignorance.

\subsubsection{Extreme events cannot be attributed to global warming but snowfall disproves global warming}

While a growing body of research has attributed a statistical increase in extreme weather events to global warming (Coumou et al. 2014; Min et al. 2011; Pall et al. 2011), attributing a single extreme weather event, such as a particular drought or flood, to observed changes in climate is still a difficult exercise. Nonetheless, recent research has increasingly attempted to attribute specific events to global warming (Hansen et al. 2012; Otto et al. 2012; Rahmstorf and Coumou 2011). In some cases, attribution can be made with considerable confidence, for example involving the ongoing Mediterranean drought (Hoerling et al. 2012; Kelley et al. 2015). In any case, the basis of the extremeevents analyses is that there is a possible causal link between those events and global warming.

Those explicit attributions of extreme events are largely ignored by contrarians, who instead focus on the-partially accurate-claim that it is problematic to attribute single extreme events as evidence for global warming (Taylor 2011). In direct contradiction to that claim, however, they also cite examples of extreme cold as evidence against global warming (Booker 2008). In one widely reported instance, a U.S. Senator (James Inhofe, R, Oklahoma) displayed a snowball in the U.S. Senate to argue against global warming. This argument assumes a causal link between global warming and the (absence of) snow or cold events, thus tacitly accepting the assumptions made in ordinary climate science. Specifically, one either admits extreme events as being at least potentially diagnostic - in which case the snowball might conceivably serve as "evidence" against global warming in the same way that droughts or heat records provide evidence for global warming - or one rejects the possibility that individual events are diagnostic because they cannot be tied to the presence (or absence) of global warming. If one rejects the diagnosticity of events, then the argumentational use of a snowball is incoherent with that rejection, but if the snowball is admitted then so should be record-breaking heat events (which outnumber record cold events by at least 2-to-1 in the U.S., Meehl et al. 2009, and by 6-to-1 or more in a recent analysis of extremes in Europe, Beniston 2015).

Either extreme events are meaningful, in which case the clear increase of some types of event underscores the presence of climate change, or extreme events cannot be linked to climate change, in which case snowfall or cold has no bearing on the issue.

\subsubsection{The Greenland ice sheet cannot collapse but Greenland used to be green in Medieval times}

If the Greenland ice sheet were to completely melt, it would contribute around 7 metres to global sea level rise (Church et al. 2013). One contrarian argument is that Greenland 
is not capable of this type of catastrophic collapse (Ollier 2007), based on the premises that Greenland's glaciers are not melting from the surface down, and that they are not sliding down an inclined plane lubricated by meltwater. Both of those premises are false (Colgan et al. 2015; Phillips et al. 2013), with ice loss from Greenland in recent years being greater than at any time since at least 1840 (Box and Colgan 2013).

At the same time, contrarians also argue that Greenland used to be green in the times of the Vikings (Bolt 2007), implying that significant amounts of the ice sheet was melted (while incidentally failing to acknowledge the metres of sea level rise that would have accompanied such a degree of melt). This argument follows the same fallacious reasoning as the common myth "past climate change disproves human role in modern global warming."

Either Greenland was so sensitive to temperature that it suffered a significant collapse in pre-Medieval times, which would imply a heightened sensitivity to contemporary human-induced warming, or Greenland is safe from collapse in which case it could not have been green during the Viking era.

\subsubsection{Other incoherent arguments}

Over one hundred incoherent pairs of arguments can be found in contrarian discourse. (See www.skepticalscience.com/contradictions.php). In this article, we have explored a representative sample in some detail. For further illustration we show several other incoherent arguments in Table 1. Each of the arguments in the table is subject to the same critical analysis as the examples in the preceding sections.

\subsection{Individual cognition vs. group behavior}

Our analysis was performed at the aggregate level; that is, we considered the incoherence of collective argumentation among a "community" of like-minded individuals as if it were a single intellectual entity. It is possible, therefore, that individuals within this community would only hold one or the other of two incoherent views, and that each person considered in isolation would not be incoherent. In that case, one could argue that there is merely a heterogeneity of views in the "community" of denialists, which might in turn be interpreted as being an indication of "healthy debate" or "scientific diversity" rather than incoherence.

We reject both the possibility and its hypothetical implication.

Our introductory quotations of Ian Plimer established that the argumentative incoherence that we analyzed in this article also arises within arguments offered by the same individual. Table 2 lists additional contradictory statements that, unlike those in Table 1, were made by the same person on separate occasions. This sample is far from exhaustive but is sufficient to establish the existence of argumentative incoherence at the level of the individual in addition to the denial movement in the aggregate.

Moreover, even if incoherence were entirely confined to being between the opinions of different individuals, there are several reasons why this would not be reflective of "healthy debate" or "scientific diversity". 
Table 1 Sample of additional incoherent arguments

\begin{tabular}{|c|c|}
\hline Argument 1 & Argument 2 \\
\hline \multicolumn{2}{|l|}{ TREND and FACT DENIAL } \\
\hline Future climate cannot be predicted & We are heading into an ice age \\
\hline Greenhouse effect has been falsifed & Water vapour is the most powerful greenhouse gas \\
\hline Paleo-temperature proxies are unreliable & The middle ages were warmer. \\
\hline Other planets are warming & It's cooling \\
\hline Global temperature does not exist & It cooled mid-century \\
\hline \multicolumn{2}{|l|}{ ATTRIBUTION DENIAL } \\
\hline Paleo-temperature proxies are unreliable & The middle ages were warmer \\
\hline Global warming theory is not falsifable & Global warming has been falsifed \\
\hline Warming causes $\mathrm{CO}_{2}$ rise & $\begin{array}{l}\text { There's no correlation between } \mathrm{CO}_{2} \text { and } \\
\text { temperature }\end{array}$ \\
\hline Mars is warming & Mars is colder despite all the $\mathrm{CO}_{2}$ \\
\hline $\mathrm{CO}_{2}$ was higher in the past & $\mathrm{CO}_{2}$ measurements are suspect \\
\hline $\mathrm{CO}_{2}$ was higher in the $1800 \mathrm{~s}$ & It warmed before 1940 when $\mathrm{CO}_{2}$ was low \\
\hline Temperature proxies are unreliable & $\mathrm{CO}_{2}$ lags temperature \\
\hline Global warming is caused by waste heat & Humans are too insignificant to affect global climate \\
\hline $\begin{array}{l}\text { Extreme events cannot be attributed to global } \\
\text { warming }\end{array}$ & Snowfall disproves global warming \\
\hline \multicolumn{2}{|l|}{ IMPACT DENIAL } \\
\hline It's not bad & There's no such thing as an ideal climate \\
\hline $\mathrm{CO}_{2}$ is plant food & $\mathrm{CO}_{2}$ is just a trace gas \\
\hline \multicolumn{2}{|l|}{ SOLUTION and POLITICAL DENIAL } \\
\hline My country should not cut emissions & Global warming is natural \\
\hline China needs to cut emissions & Global warming is unstoppable \\
\hline Global warming is a socialist plot & The Nazis invented global warming \\
\hline
\end{tabular}

First, as we noted at the outset, science strives for coherence (e.g., Douglas 2013; Laudan 1984; Roche 2014; Thagard 2012) and there is little room for incoherent theories in science (and any incoherence contains within it an impetus for reconciliation). The scientific consensus on climate change embodied in the IPCC reports represents a coherent body of knowledge that draws an arc from the microscale of molecular chemistry (viz. the heat absorbing properties of $\mathrm{CO}_{2}$ ) to the macroscale of a suite of global indicators (viz. global temperatures, sea level rise, mass loss in the cryosphere, and so on). This coherence is attained even though several thousands of scientists are involved in production of the report as authors and reviewers. It follows that if climate denial were to constitute scientific reasoning - as is its purported purpose (e.g., Solomon 2008) - then it would exhibit coherence notwithstanding the presence of multiple agents and actors. The fact that it fails to achieve this and that incoherence is manifest at the aggregate (Table 1) as well as at the individual level (Table 2) leaves little doubt about the non-scientific nature of denial. 


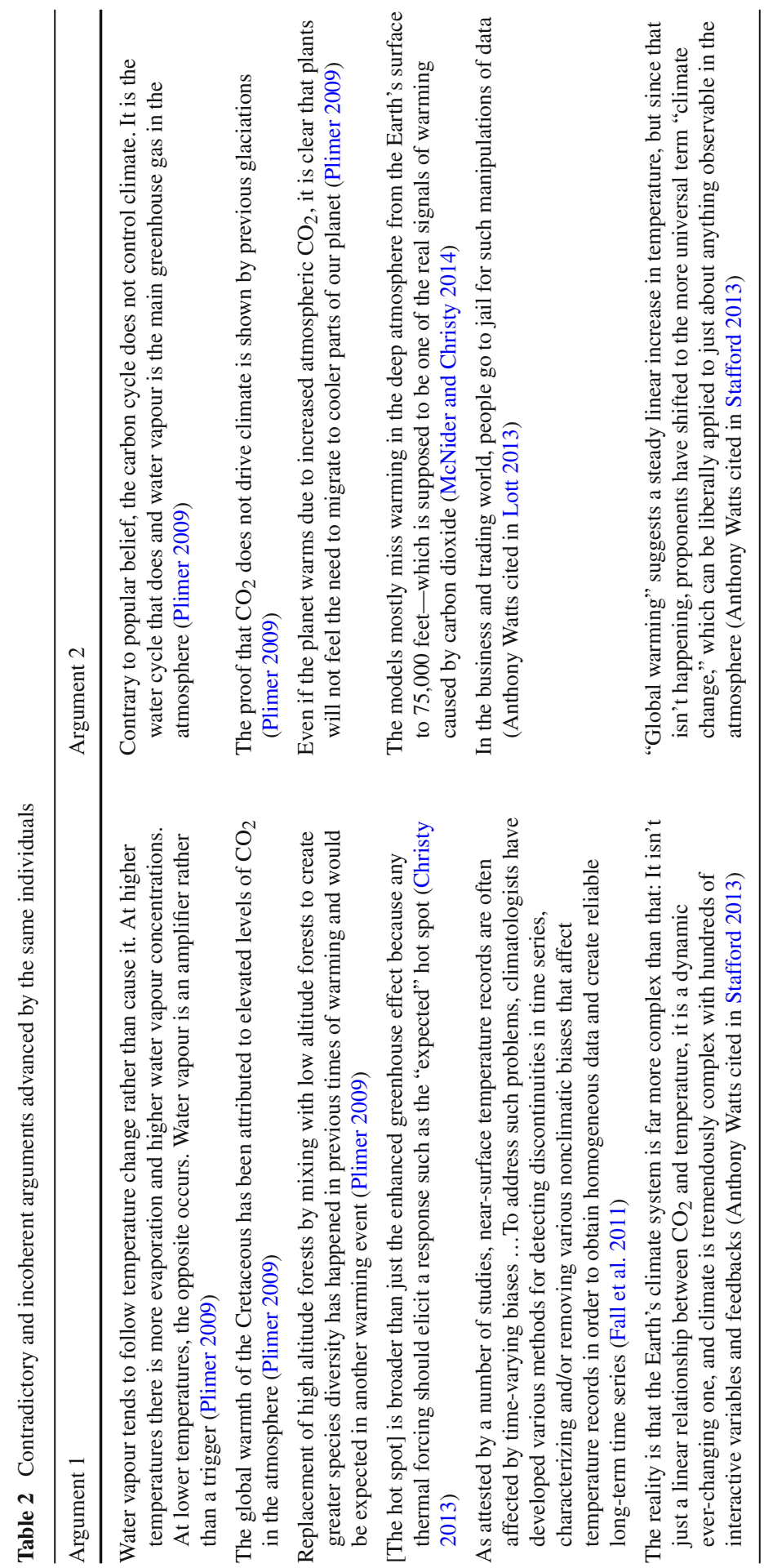




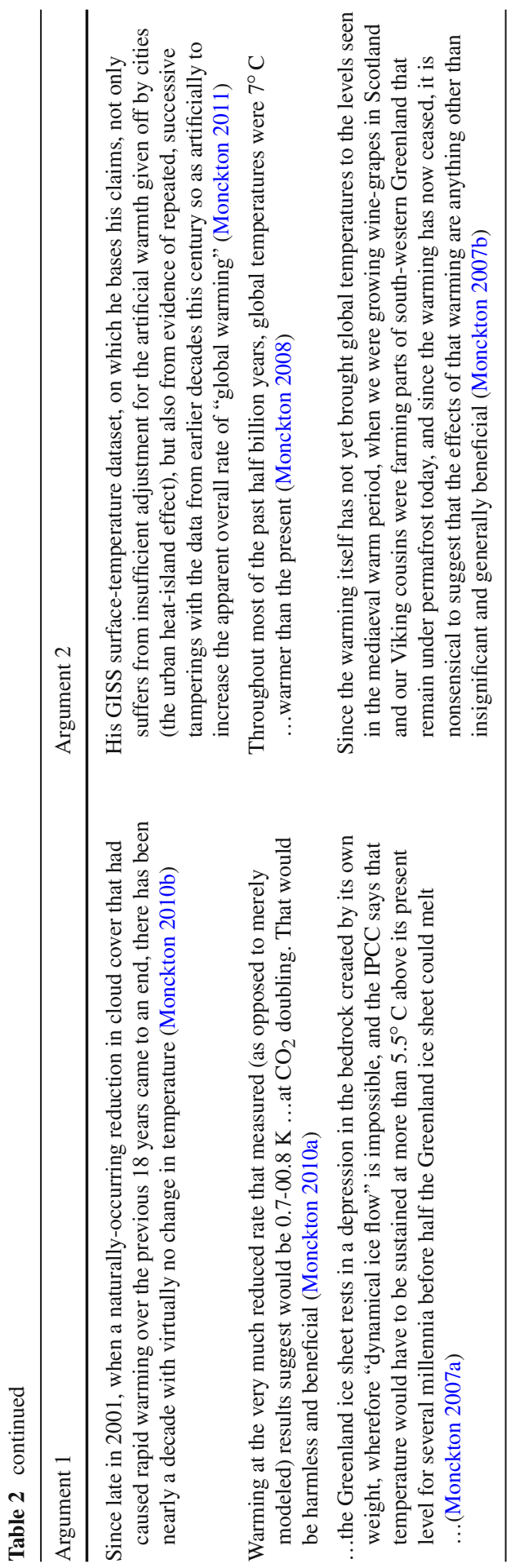


Second, the theoretical coherence of consensual climate science does not prevent robust debate. One striking example involves the recent controversy about the socalled "pause" or "hiatus" in global warming in the early 2000's. Some scientists have argued against the existence or special status of this "pause" (e.g., Cahill et al. 2015; Foster and Rahmstorf 2011; Foster and Abraham 2015; Karl et al. 2015; Lewandowsky et al. 2015c, d) whereas others have taken a contrary position (Fyfe et al. 2016; Trenberth 2015). We therefore argue that science achieves its coherence through a constant self-correction process (e.g., Alberts et al. 2015; Longino 1990, 2002) that occurs through peer-review, journal articles, conference communications, graduate training, mentoring, and so on. Scientific debate is a key element of achieving scientific coherence (Leuschner 2012). No such corrective processes can be observed in denialist discourse which focuses entirely on its opposition to mainstream science and does not entail any debate among the incoherent positions we have revealed in this article.

The absence of any corrective resolution process among climate contrarians raises the question to what extent incoherence is perceived or recognized as a problem by people who hold contrarian views. This question is difficult to answer with any degree of certainty, although one can attempt to make an inference by examining the "revealed preferences" (cf. Beshears et al. 2008) of contrarians. In the context of climate change, one way in which preferences might be revealed is by the willingness to incur financial risks to back one's position in a bet. Bets have a long history as a tool to reveal people's preferences.

Risbey et al. (2015) analyzed the actual historical and likely future odds of a number of different betting strategies on global temperatures from the late 19th century to 2100. Risbey et al. found that all possible 15-year bets since 1970 were won by bettors positing continued warming, and that bets against greenhouse warming are largely hopeless now.

It is notable that although contrarians readily claim that the Earth will be cooling in the future, most are unwilling to bet on their stated position (Annan 2005). The experiences of Nobel Laureate Brian Schmidt, of the Australian National University, who offered a bet to an Australian "skeptic" (a business adviser of former Prime Minister Tony Abbott) are illuminating in this regard (Cook 2015). The widespread reluctance to engage in bets by contrarians suggests that their public posture differs from their actual knowledge, and that they know that any such bet would be hopeless (Risbey et al. 2015). The unwillingness to bet is thus indicative of the over-arching rationality of denial, notwithstanding its argumentative incoherence and non-scientific nature.

\subsection{Rational denial}

Unlike mainstream science, which is regularly summarized in the IPCC's Assessment Reports, contrarian positions are more diverse, and are spread across a multitude of sources-from internet blogs, to reports produced by "think tanks" (Jacques et al. 2008), to popular books (Dunlap and Jacques 2013). Although this diversity makes it challenging to identify the over-arching level of abstraction at which contrarian 
positions may achieve the coherence that is lacking in their (pseudo-) scientific arguments, there is little doubt that the common denominator among contrarian positions is the conviction that climate change either does not exist or is not human caused, and that either way it does not present a risk (or if it does, then adaptation will deal with the problem). Any mitigation efforts would thus be misplaced and add an unnecessary burden on the economy. In a nutshell, the opposition to GHG emission cuts is the unifying and coherent position underlying all manifestations of climate science denial.

Accordingly, contrarian activities are supported by the injection of considerable funds by vested and political interests (Brulle 2013); most climate-"skeptic" books have links to conservative think tanks (Dunlap and Jacques 2013); and fossil-fuel interests have interfered with scientific assessments (Mooney 2007). As noted earlier, Thagard and Findlay (2011) have shown that when those political goals are represented as strong emotional components within a rational belief system that is devoted to seek maximal coherence, the system will adopt a "skeptic" position notwithstanding the fact that it is less commensurate with the evidence than the mainstream scientific position. Similarly, Cook and Lewandowsky (2016) have shown within a Bayesian framework that ironic updating of beliefs - that is, becoming more entrenched in one's position in light of contrary evidence-can be modeled by a rational belief-updating system under some circumstances. In Cook and Lewandowsky (2016)'s study, participants who strongly supported free-market economics responded to climate-consensus information by lowering their acceptance of human-caused global warming. This ironic "backfire" effect was identified as being rational because people adjusted their trust in climate scientists downward, thereby accommodating information about the consensus without requiring an adjustment of belief in the science-because if scientists cannot be trusted, then they would likely collude to create the appearance of a consensus.

If the coherent goal of contrarian activities is the prevention of political action, then argumentative incoherence-or other manifestations of conspiracist thoughtare irrelevant, from the contrarians' perspective, so long as it does not interfere with achievement of that goal. There is some evidence that conspiratorial content is not detrimental to achieving the objectives of preventing or delaying policy action. On the contrary, it has been shown that the mere exposure to conspiracy theories involving global warming decreases pro-environmental decision making and the intention to reduce one's carbon footprint (Jolley and Douglas 2013; van der Linden 2015). Similarly, McCright et al. (2016) and Ranney and Clark (2016) have shown that exposure to misleading statistics about climate change - and many contrarian claims are judged to be misleading and inaccurate in a blind expert test (Lewandowsky et al. 2016) — can adversely impact people's attitudes.

Perhaps even more concerning is the possibility that denial has also affected the course of climate science itself, a proposal that was independently put forward by the first author and colleagues under the label "seepage" (Lewandowsky et al. 2015b,d) and by Biddle and Leuschner (2015) under the label "bad dissent." Common to both proposals is the idea that denial has impeded scientific progress, notwithstanding the crucial role of normal dissent and debate in science: 
Dissent can be beneficial even if it is based on low quality research, as it can provoke discussion and, thus, lead to a fuller understanding of the state of knowledge. In order for dissent to be epistemically problematic, it must not only be based on low quality research (or research that violates established conventional standards), it must also impede scientific progress.

Unfortunately, dissent in some areas of science is increasingly doing just this; more and more, it is being used by stakeholders to undermine the authority of science in order to postpone inconvenient political action. In climate science, contrarian studies are often disseminated through networks established by conservative think tanks and then used as a basis for both personal and professional attacks on climate scientists. We have shown that there is strong empirical evidence that the attacks have an influence on the work of these scientists and hence on the progress of climate science (Biddle and Leuschner 2015, p. 276).

Thus, from a purely pragmatic perspective, we know of no discernible cost - in terms of political effectiveness - of the conspiracist, incoherent, and misleading aspects of contrarian discourse. As a political strategy, organized denial of climate science appears to "work"- a judgment supported by the fact that written material arguing against mainstream science conveys greater certainty, and hence may have greater persuasive impact, than scientifically-founded material (Medimorec and Pennycook 2015).

\section{Conclusion}

There is considerable evidence that the rejection of (climate) science involves a component of conspiracist discourse. In this article, we provided preliminary evidence that the pseudo-scientific arguments that underpin climate science denial are mutually incoherent, which is a known attribute of conspiracist ideation. The lack of mechanisms to self-correct the scientific incoherencies manifest in denialist discourse further evidences that this is not the level at which rational activity is focused, and we must move to a higher level, looking at the role of conspiracist ideation in the political realm. At that political level, climate denial achieves coherence in its uniform and unifying opposition to GHG emission cuts. The coherent political stance of denial may not be undercut by its scientific incoherence. Climate science denial is therefore perhaps best understood as a rational activity that replaces a coherent body of science with an incoherent and conspiracist body of pseudo-science for political reasons and with considerable political coherence and effectiveness.

Acknowledgements Preparation of this paper was facilitated by a Wolfson Research Merit Award from the Royal Society to the first author. During part of this work, the first author was also supported by a grant from the Australian Research Council and he received funding from the Psychonomic Society. We thank James Risbey for comments on an earlier draft of this article.

Open Access This article is distributed under the terms of the Creative Commons Attribution 4.0 International License (http://creativecommons.org/licenses/by/4.0/), which permits unrestricted use, distribution, and reproduction in any medium, provided you give appropriate credit to the original author(s) and the source, provide a link to the Creative Commons license, and indicate if changes were made. 


\section{References}

Abraham, J. P., Cook, J., Fasullo, J. T., Jacobs, P. H., Mandia, S. A., \& Nuccitelli, D. A. (2014). Review of the consensus and asymmetric quality of research on human-induced climate change. Cosmopolis, 1 , 3-18.

Alberts, B., Cicerone, R. J., Fienberg, S. E., Kamb, A., McNutt, M., Nerem, R. M., et al. (2015). Selfcorrection in science at work. Science, 348, 1420-1422. doi:10.1126/science.aab3847.

Anderegg, W. R. L., Prall, J. W., Harold, J., \& Schneider, S. H. (2010). Expert credibility in climate change. Proceedings of the National Academy of Sciences, 107, 12107-12109. doi:10.1073/pnas.1003187107.

Anderson, E. (2011). Democracy, public policy, and lay assessments of scientific testimony. Episteme, 8, 144-164. doi:10.3366/epi.2011.0013.

Annan, J. (2005, June). Betting on climate change. Retrieved from http://www.realclimate.org/index.php/ archives/2005/06/betting-on-climate-change/.

Bale, J. M. (2007). Political paranoia v. political realism: On distinguishing between bogus conspiracy theories and genuine conspiratorial politics. Patterns of Prejudice, 41, 45-60. doi:10.1080/ 00313220601118751.

Beck, E. G. (2008). 50 years of continuous measurement of $\mathrm{CO}_{2}$ on Mauna Loa. Energy \& Environment, 19, 1017-1028.

Benestad, R., Nuccitelli, D., Lewandowsky, S., Hayhoe, K., Hygen, H., van Dorland, R., et al. (2015). Learning from mistakes in climate research. Theoretical and Applied Climatology. doi:10.1007/s00704-0151597-5.

Beniston, M. (2015). Ratios of record high to record low temperatures in Europe exhibit sharp increases since 2000 despite a slowdown in the rise of mean temperatures. Climatic Change, 129, 225-237. doi:10.1007/s10584-015-1325-2.

Beshears, J., Choi, J. J., Laibson, D., \& Madrian, B. C. (2008). How are preferences revealed? Journal of Public Economics, 92, 1787-1794.

Biddle, J. B., \& Leuschner, A. (2015). Climate skepticism and the manufacture of doubt: Can dissent in science be epistemically detrimental? European Journal for Philosophy of Science, 5, 261-278. doi:10. 1007/s13194-014-0101-x.

Bogart, L. M., \& Thorburn, S. (2005). Are HIV/AIDS conspiracy beliefs a barrier to HIV prevention among African Americans? Journal of Acquired Immune Deficiency Syndromes, 38, 213-218. doi:10.1097/ 00126334-200502010-00014.

Bolt, A. (2007). Greenland celebrates local warming. Retrieved from http://blogs.news.com.au/heraldsun/ andrewbolt/index.php/heraldsun/comments/greenland_celebrates_local_warming/.

Booker, C. (2008). 2008 was the year man-made global warming was disproved. Retrieved from http://www.telegraph.co.uk/comment/columnists/christopherbooker/3982101/2008-was-the-ye ar-man-made-global-warming-was-disproved.html.

Box, J. E., \& Colgan, W. (2013). Greenland ice sheet mass balance reconstruction. Part III: Marine ice loss and total mass balance (1840-2010). Journal of Climate, 26, 6990-7002. doi:10.1175/JCLI-D-1200546.1 .

Boykoff, M. T. (2014). Media discourse on the climate slowdown. Nature Climate Change, 4, 156-158. doi:10.1038/nclimate2156.

Briones, R., Nan, X., Madden, K., \& Waks, L. (2012). When vaccines go viral: An analysis of HPV vaccine coverage on YouTube. Health Communication, 27, 478-485. doi:10.1080/10410236.2011.610258.

Brulle, R. J. (2013). Institutionalizing delay: Foundation funding and the creation of US climate change counter-movement organizations. Climatic Change, 122, 681-694. doi:10.1007/s10584-013-1018-7.

Cahill, N., Rahmstorf, S., \& Parnell, A. C. (2015). Change points of global temperature. Environmental Research Letters, 10, 084002.

Carter, B. (2006, April). There is a problem with global warming... it stopped in 1998. Retrieved from http://www.telegraph.co.uk/comment/personalview/3624242/There-IS-a-problem-with-global-war ming...-it-stopped-in-1998.html.

Christy, J. (2013). Comment on 'The (missing) tropical hot spot'. Retrieved from http://www. climatedialogue.org/the-missing-tropical-hot-spot/\#comment-754.

Church, J., Clark, P., Cazenave, A., Gregory, J., Jevrejeva, S., Levermann, A., et al. (2013). Climate change 2013: The physical science basis. Contribution of working group I to the Fifth Assessment Report of the Intergovernmental Panel on Climate Change. In T. Stocker, et al. (Eds.), Sea level change (p. 1137-1216). Cambridge: Cambridge University Press. doi:10.1017/CBO9781107415324.026. 
Colgan, W., Sommers, A., Rajaram, H., Abdalati, W., \& Frahm, J. (2015). Considering thermal-viscous collapse of the Greenland ice sheet. Earth's Future, 3, 252-267. doi:10.1002/2015EF000301.

Cook, J. (2015). [denial101x] Nobel laureate Brian Schmidt on betting on future climate change [Video file]. University of Queensland. Retrieved from https://www.youtube.com/watch?v=zsfQaOGW1Zk.

Cook, J., \& Lewandowsky, S. (2016). Rational irrationality: Modeling climate change belief polarization using Bayesian networks. Topics in Cognitive Science, 8, 160-179. doi:10.1111/tops.12186.

Cook, J., Nuccitelli, D., Green, S. A., Richardson, M., Winkler, B., Painting, R., et al. (2013). Quantifying the consensus on anthropogenic global warming in the scientific literature. Environmental Research Letters, 8, 024024. doi:10.1088/1748-9326/8/2/024024.

Cook, J., Oreskes, N., Doran, P., Anderegg, W., Verheggen, B., Maibach, E., et al. (2016). Consensus on consensus: A synthesis of consensus estimates on human-caused global warming. Environmental Research Letters, 11, 048002. doi:10.1088/1748-9326/11/4/048002.

Coumou, D., Petoukhov, V., Rahmstorf, S., Petri, S., \& Schellnhuber, H. J. (2014). Quasi-resonant circulation regimes and hemispheric synchronization of extreme weather in boreal summer. Proceedings of the National Academy of Sciences, 111, 12331-12336. doi:10.1073/pnas.1412797111.

Diethelm, P., \& McKee, M. (2009). Denialism: What is it and how should scientists respond? European Journal of Public Health, 19, 2-4. doi:10.1093/eurpub/ckn139.

Doran, P. T., \& Zimmerman, M. K. (2009). Examining the scientific consensus on climate change. Eos, 90(3), 21-22. doi:10.1029/2009EO030002.

Douglas, H. (2013). The value of cognitive values. Philosophy of Science, 80, 796-806. doi:10.1086/673716.

Dunlap, R. E., \& Jacques, P. J. (2013). Climate change denial books and conservative think tanks: Exploring the connection. American Behavioral Scientist, 57, 1-33. doi:10.1177/0002764213477096.

Dunlap, R. E., \& McCright, A. M. (2008). A widening gap: Republican and Democratic views on climate change. Environment: Science and Policy for Sustainable Development, 50, 26-35. doi:10.3200/ ENVT.50.5.26-35.

Dunlap, R. E., \& McCright, A. M. (2010). Climate change denial: Sources, actors, and strategies. In C. Lever-Tracy (Ed.), Handbook of climate change and society (pp. 240-259). Abingdon: Routledge.

Dunlap, R. E., \& McCright, A. M. (2011). Organized climate change denial. In J. S. Dryzek, R. B. Norgaard, \& D. Schlosberg (Eds.), The Oxford handbook of climate change and society (pp. 144-160). Oxford: Oxford University Press.

Elsasser, S. W., \& Dunlap, R. E. (2013). Leading voices in the denier choir: Conservative columnists' dismissal of global warming and denigration of climate science. American Behavioral Scientist, 57, 754-776. doi:10.1177/0002764212469800.

Fall, S., Watts, A., Nielsen-Gammon, J., Jones, E., Niyogi, D., Christy, J.R., \& Pielke, R.A. (2011). Analysis of the impacts of station exposure on the US Historical Climatology Network temperatures and temperature trends. Journal of Geophysical Research. doi:10.1029/2010JD015146.

Feulner, G., \& Rahmstorf, S. (2010). On the effect of a new grand minimum of solar activity on the future climate on Earth. Geophysical Research Letters, 37, L05707. doi:10.1029/2010GL042710.

Foster, G., \& Abraham, J. (2015). Lack of evidence for a slowdown in global temperature. US CLIVAR, 13(3), 6-9.

Foster, G., \& Rahmstorf, S. (2011). Global temperature evolution 1979-2010. Environmental Research Letters, 6, 044022. doi:10.1088/1748-9326/6/4/044022.

Freeman, M. C., Wagner, G., \& Zeckhauser, R. J. (2015). Climate sensitivity uncertainty: When is good news bad? Philosophical Transactions of the Royal Society of London A, 373, 20150092. doi:10.1098/ rsta.2015.0092.

Fyfe, J. C., Meehl, G. A., England, M. H., Mann, M. E., Santer, B. D., Flato, G. M., et al. (2016). Making sense of the early-2000s warming slowdown. Nature Climate Change, 6, 224-228.

Glass, D. H. (2007). Coherence measures and inference to the best explanation. Synthese, 157, $275-296$.

Hansen, J., Sato, M., \& Ruedy, R. (2012). Perception of climate change. Proceedings of the National Academy of Sciences, 109, E2415-E2423. doi:10.1073/pnas.1205276109.

Hickman, M. (2010). Global warming is 'bulls**t' says Ryanair boss O’Leary. Retrieved from http://www. independent.ie/business/irish/global-warming-is-bullst-says-ryanair-boss-oleary-26679424.html.

Hoerling, M., Eischeid, J., Perlwitz, J., Quan, X., Zhang, T., \& Pegion, P. (2012). On the increased frequency of mediterranean drought. Journal of Climate, 25, 2146-2161.

IPCC. (2013). Summary for policymakers. In T. Stocker (Ed.), Climate change 2013: The physical science basis. Contribution of working group I to the Fifth Assessment Report of the Intergovernmental Panel on 
Climate Change (p.130). Cambridge: Cambridge University Press. doi:10.1017/CBO9781107415324. 004.

Jacques, P. J., Dunlap, R. E., \& Freeman, M. (2008). The organisation of denial: Conservative think tanks and environmental scepticism. Environmental Politics, 17, 349-385. doi:10.1080/09644010802055576.

Jang, S. M., \& Hart, P. S. (2015). Polarized frames on "climate change" and "global warming" across countries and states: Evidence from Twitter big data. Global Environmental Change, 32, 11-17. doi:10.1016/j.gloenvcha.2015.02.010.

Jaworowski, Z. (1997). Ice core data show no carbon dioxide increase. Retrieved from http://www. 21stcenturysciencetech.com/2006_articles/IceCoreSprg97.pdf.

Johnson, B. (2013). It's snowing, and it really feels like the start of a mini ice age. Retrieved from http://www.telegraph.co.uk/comment/columnists/borisjohnson/9814618/Its-snowing-and-it-re ally-feels-like-the-start-of-a-mini-ice-age.html.

Jolley, D., \& Douglas, K. M. (2013). The social consequences of conspiracism: Exposure to conspiracy theories decreases intentions to engage in politics and to reduce one's carbon footprint. British Journal of Psychology, 105, 35-56. doi:10.1111/bjop.12018.

Kahan, D. M., Braman, D., Gastil, J., Slovic, P., \& Mertz, C. K. (2007). Culture and identity-protective cognition: Explaining the white-male effect in risk perception. Journal of Empirical Legal Studies, 4 , 465-505.

Kalichman, S. C. (2009). Denying AIDS: Conspiracy theories, pseudoscience, and human tragedy. New York: Springer.

Karl, T. R., Arguez, A., Huang, B., Lawrimore, J. H., McMahon, J. R., Menne, M. J., et al. (2015). Possible artifacts of data biases in the recent global surface warming hiatus. Science, 348, 1469-1472. doi:10. $1126 /$ science.aaa5632.

Kata, A. (2010). A postmodern Pandoras box: Anti-vaccination misinformation on the Internet. Vaccine, 28, 1709-1716. doi:10.1016/j.vaccine.2009.12.022.

Keeley, B. L. (1999). Of conspiracy theories. The Journal of Philosophy, 96, 109-126. doi:10.2307/2564659.

Kelley, C. P., Mohtadi, S., Cane, M. A., Seager, R., \& Kushnir, Y. (2015). Climate change in the Fertile Crescent and implications of the recent Syrian drought. Proceedings of the National Academy of Sciences, 112, 3241-3246. doi:10.1073/pnas.1421533112.

Laudan, L. (1984). Science and values: The aims of science and their role in scientific debate. Berkeley: University of California Press.

Leuschner, A. (2012). Pluralism and objectivity: Exposing and breaking a circle. Studies in History and Philosophy of Science, 43, 191-198. doi:10.1016/j.shpsa.2011.12.030.

Lewandowsky, S., Oreskes, N., Risbey, J. S., Newell, B. R., \& Smithson, M. (2015b). Seepage: Climate change denial and its effect on the scientific community. Global Environmental Change, 33, 1-13. doi:10.1016/j.gloenvcha.2015.02.013.

Lewandowsky, S., Risbey, J. S., \& Oreskes, N. (2015d). The "pause" in global warming: Turning a routine fluctuation into a problem for science. Bulletin of the American Meteorological Society. doi:10.1175/ BAMS-D-14-00106.1.

Lewandowsky, S. (2014). Conspiratory fascination vs. public interest: The case of 'climategate'. Environmental Research Letters, 9, 111004.

Lewandowsky, S., Ballard, T., Oberauer, K., \& Benestad, R. (2016). A blind expert test of contrarian claims about climate data. Global Environmental Change, 39, 91-97.

Lewandowsky, S., Cook, J., Oberauer, K., Brophy, S., Lloyd, E. A., \& Marriott, M. (2015a). Recurrent fury: Conspiratorial discourse in the blogosphere triggered by research on the role of conspiracist ideation in climate denial. Journal of Social and Political Psychology, 3, 142-178. doi:10.5964/jspp.v3i1.443.

Lewandowsky, S., Gignac, G. E., \& Oberauer, K. (2013a). The role of conspiracist ideation and worldviews in predicting rejection of science. PLoS One, 8, e75637. doi:10.1371/journal.pone.0075637.

Lewandowsky, S., Gignac, G. E., \& Vaughan, S. (2013b). The pivotal role of perceived scientific consensus in acceptance of science. Nature Climate Change, 3, 399-404. doi:10.1038/nclimate1720.

Lewandowsky, S., Oberauer, K., \& Gignac, G. E. (2013c). NASA faked the moon landing-therefore (climate) science is a hoax: An anatomy of the motivated rejection of science. Psychological Science, 24, 622633. doi:10.1177/0956797612457686.

Lewandowsky, S., Risbey, J. S., \& Oreskes, N. (2015c). On the definition and identifiability of the alleged "hiatus" in global warming. Scientific Reports, 5, 16784. doi:10.1038/srep16784. 
Lewandowsky, S., Risbey, J. S., Smithson, M., Newell, B. R., \& Hunter, J. (2014). Scientific uncertainty and climate change: Part I. Uncertainty and unabated emissions. Climatic Change, 124, 21-37. doi:10. 1007/s10584-014-1082-7.

Lewis, N., \& Curry, J. A. (2014). The implications for climate sensitivity of AR5 forcing and heat uptake estimates. Climate Dynamics, 45, 1009-1023. doi:10.1007/s00382-014-2342-y.

Longino, H. E. (1990). Science as social knowledge. Princeton: Princeton University Press.

Longino, H. E. (2002). The fate of knowledge. Princeton: Princeton University Press.

Lott, M. (2013). Hottest year ever? Skeptics question revision to climate data. Retrived from http://www. foxnews.com/science/2013/01/10/hottestyear-ever-skeptics-question-revisions-to-climate-data.html.

Mann, M. E. (2015). The Serengeti strategy: How special interests try to intimidate scientists, and how best to fight back. Bulletin of the Atomic Scientists, 71, 33-45. doi:10.1177/0096340214563674.

Masson-Delmotte, V., Schulz, M., Abe-Ouchi, A., Beer, J., Ganopolski, A., GonzalezRouco, J., et al. (2013). Information from paleoclimate archives. In T. Stocker (Ed.), Climate change 2013: The physical science basis. Contribution of Working Group I to the Fifth Assessment Report of the Intergovernmental Panel on Climate Change (pp. 383-464). Cambridge: Cambridge University Press. doi:10.1017/ CBO9781107415324.013.

McCright, A. M., Charters, M., Dentzman, K., \& Dietz, T. (2016). Examining the effectiveness of climate change frames in the face of a climate change denial counter-frame. Topics in Cognitive Science. 8 , 76-97 doi:10.1111/tops.12171.

McCright, A. M., Dentzman, K., Charters, M., \& Dietz, T. (2013). The influence of political ideology on trust in science. Environmental Research Letters, 8, 044029.

McCright, A. M., Dunlap, R. E., \& Xiao, C. (2014). Increasing influence of party identification on perceived scientific agreement and support for government action on climate change in the United States, 200612. Weather Climate and Society, 6, 194-201. doi:10.1175/WCAS-D-13-00058.1.

McKee, M., \& Diethelm, P. (2010). Christmas 2010: Reading between the lines how the growth of denialism undermines public health. British Medical Journal, 341, 1309-1311. doi:10.1136/bmj.c6950.

McNider, R., \& Christy, J. (2014). Why Kerry is flat wrong on climate change. Retrievedfrom http://www. wsj.com/news/articles/SB10001424052702303945704579391611041331266.

Medimorec, S., \& Pennycook, G. (2015). The language of denial: Text analysis reveals differences in language use between climate change proponents and skeptics. Climatic Change, 133, 597-605. doi:10. 1007/s10584-015-1475-2.

Meehl, G. A., Tebaldi, C., Walton, G., Easterling, D., \& McDaniel, L. (2009). Relative increase of record high maximum temperatures compared to record low minimum temperatures in the U.S. Geophysical Research Letters, 36, L23701. doi:10.1029/2009GL040736.

Min, S. K., Zhang, X., Zwiers, F. W., \& Hegerl, G. C. (2011). Human contribution to more-intense precipitation extremes. Nature, 470, 378-381. doi:10.1038/nature09763.

Monckton, C. (2007a, October). 35 inconvenient truths: The errors in Al Gore's movie. Retrieved from http://ben-israel.rutgers.edu/711/monckton-response-to-gore-errors.pdf.

Monckton, C. (2007b, October). Trenberth's twenty-three scientific errors in one short article. Retrieved from http://scienceandpublicpolicy.org/images/stories/papers/monckton/23_trenberth_errors.pdf.

Monckton, C. (2008, December). Coolest year for a decade means more 'global warming' to come. Retrieved from http://scienceandpublicpolicy.org/images/stories/papers/scarewatch/Guardian-Cool est_Year_For_Decade.pdf.

Monckton, C. (2010a, May). Testimony of the Viscount Monckton of Brenchley before Congress 6 May 2010. Retrieved from http://scienceandpublicpolicy.org/images/stories/papers/reprint/viscount_ congress_testimony_may_2010.pdf.

Monckton, C. (2010b, October). Unsound advice: A critique of John Holdren's September 2010 speech entitled "Climate-Change Science and Policy: What Do We Know? What Should We Do?". Retrieved from http://scienceandpublicpolicy.org/images/stories/papers/originals/unsound_advice.pdf.

Monckton, C. (2011, January). Alarming warming? Reality trumps dire predictions. Retrieved from http:// scienceandpublicpolicy.org/images/stories/papers/originals/alarming_warming.pdf.

Mooney, C. (2007). An inconvenient assessment. Bulletin of the Atomic Scientists, 63(6), 40-47.

Ollier, C. (2007). The Greenland-Antarctica melting problem does not exist. Retrieved from http://hallolinden-db.de/baseportal?htx=/hallolinden-db.de/Klima/Klima\&cmd=list\&range=0, $100 \&$ Datum $==\& \mathrm{cmd}=$ all $\& \mathrm{Id}=1680$.

Olsson, E. J. (2005). Against coherence: Truth, probability and justification. Oxford: Oxford University Press. 
Oreskes, N. (1999). The rejection of continental drift: Theory and method in American earth science. New York: Oxford University Press.

Oreskes, N. (2004). The scientific consensus on climate change. Science, 306, 1686. doi:10.1126/science. 1103618.

Oreskes, N., \& Conway, E. M. (2010). Merchants of doubt. London: Bloomsbury Publishing.

Otto, F. E. L., Massey, N., van Oldenborgh, G. J., Jones, R. G., \& Allen, M. R. (2012). Reconciling two approaches to attribution of the 2010 Russian heat wave. Geophysical Research Letters, 39, L04702. doi:10.1029/2011GL050422.

PALAEOSENS. (2012). Making sense of palaeoclimate sensitivity. Nature, 491, 683-691. doi:10.1038/ nature 11574.

Pall, P., Aina, T., Stone, D. A., Stott, P. A., Nozawa, T., Hilberts, A. G. J., et al. (2011). Anthropogenic greenhouse gas contribution to flood risk in England and Wales in autumn 2000. Nature, 470, 382-385. doi:10.1038/nature09762.

Phillips, T., Rajaram, H., Colgan, W., Steffen, K., \& Abdalati, W. (2013). Evaluation of cryo-hydrologic warming as an explanation for increased ice velocities in the wet snow zone, Sermeq Avannarleq, West Greenland. Journal of Geophysical Research: Earth Surface, 118, 1241-1256. doi:10.1002/jgrf. 20079.

Plimer, I. (2010, December). Volcanoes, earthquakes and carbon dioxide. Retrieved from http://carbonsense.com/2011/04/01/plimer-earthquakes-volcanoes-carbon-dioxide/.

Plimer, I. (2009). Heaven and Earth: Global warming the missing science. Ballan, VIC: Connor Court Publishing.

Rahmstorf, S., \& Coumou, D. (2011). Increase of extreme events in a warming world. Proceedings of the National Academy of Sciences, 108, 17905-17909. doi:10.1073/pnas.1101766108.

Ranney, M.A., \& Clark, D. (2016). Climate change conceptual change: Scientific information can transform attitudes. Topics in Cognitive Science, 8, 49-75. doi:10.1111/tops.12187.

Risbey, J. S., Lewandowsky, S., Hunter, J. R., \& Monselesan, D. P. (2015). Betting strategies on fluctuations in the transient response of greenhouse warming. Philosophical Transactions of the Royal Society (A), 373, 20140463. doi:10.1098/rsta.2014.0463.

Roche, W. (2014). On the truth-conduciveness of coherence. Erkenntnis, 79, 647-665. doi:10.1007/s10670013-9564-y.

Rose, D. (2010, January). The mini ice age starts here. Retrieved from http://www.dailymail.co.uk/ sciencetech/article-1242011/DAVID-ROSE-The-mini-ice-age-starts-here.html.

Schubert, S. (2012). Coherence reasoning and reliability: A defense of the Shogenji measure. Synthese, 187, 305-319.

Shakun, J. D., Clark, P. U., He, F., Marcott, S. A., Mix, A. C., Liu, Z., et al. (2012). Global warming preceded by increasing carbon dioxide concentrations during the last deglaciation. Nature, 484, 49-55.

Shwed, U., \& Bearman, P. S. (2010). The temporal structure of scientific consensus formation. American Sociological Review, 75, 817-840. doi:10.1177/0003122410388488.

Smith, N., \& Leiserowitz, A. (2012). The rise of global warming skepticism: Exploring affective image associations in the United States over time. Risk Analysis, 32, 1021-1032. doi:10.1111/j.1539-6924. 2012.01801.x.

Smith, T. M., Peterson, T. C., Lawrimore, J. H., \& Reynolds, R. W. (2005). New surface temperature analyses for climate monitoring. Geophysical Research Letters, 32, L14712. doi:10.1029/2005GL023402.

Solomon, L. (2008). The deniers: The world renowned scientists who stood up against global warming hysteria, political persecution, and fraud and those who are too fearful to do so. Minneapolis, MN: Richard Vigilante Books.

Stafford, J. (2013). Climate change without catastrophe: Interview with Anthony Watts. Retrieved from http://oilprice.com/Interviews/Climate-Change-without-Catastrophe-Interview-with-Anthony-Watt s.html.

Sunstein, C. R., \& Vermeule, A. (2009). Conspiracy theories: Causes and cures. Journal of Political Philosophy, 17, 202-227. doi:10.1111/j.1467-9760.2008.00325.x.

Taylor, J.M. (2011). Extreme weather and global warming. Retrieved from http://articles.chi cagotribune.com/2011-02-14/opinion/chi-110214taylor_briefs_1_global-warming-restrictions-on-c arbon-dioxide-extreme-weather.

Thagard, P. (2012). Coherence: The price is right. The Southern Journal of Philosophy, 50, 42-49. 
Thagard, P., \& Findlay, S. D. (2011). Changing minds about climate change: Belief revision, coherence, and emotion. In E. J. Olsson \& S. Enqvist (Eds.), Belief revision meets philosophy of science (pp. 329-345). Berlin: Springer.

Trenberth, K. E. (2015). Has there been a hiatus? Science, 349, 691-692. doi:10.1126/science.aac9225.

van der Linden, S. (2015). The conspiracy-effect: Exposure to conspiracy theories (about global warming) decreases pro-social behavior and science acceptance. Personality and Individual Differences, 87, 171-173. doi:10.1016/j.paid.2015.07.045.

van der Linden, S. L., Leiserowitz, A. A., Feinberg, G. D., \& Maibach, E. W. (2015). The scientific consensus on climate change as a gateway belief: Experimental evidence. PLoS One, 10, e0118489. doi:10.1371/ journal.pone.0118489.

Watts, A. (2009). Is the US surface temperature record reliable. Technical Report, The Heartland Institute, Chicago, IL.

Wood, M. J., Douglas, K. M., \& Sutton, R. M. (2012). Dead and alive: Beliefs in contradictory conspiracy theories. Social Psychological and Personality Science, 3, 767-773. doi:10.1177/1948550611434786.

Zimmerman, R. K., Wolfe, R. M., Fox, D. E., Fox, J. R., Nowalk, M. P., Troy, J. A., et al. (2005). Vaccine criticism on the World Wide Web. Journal of Medical Internet Research, 7, e17. doi:10.2196/jimr.7. 2.e17. 